FACUNDO AND THE CONSTRUCTION OF ARGENTINE CULTURE 
The Texas Pan American Series 


\title{
FACUNDO AND THE CONSTRUCTION OF ARGENTINE CULTURE
}

\author{
$\sim$ \\ BY DIANA SORENSEN GOODRICH
}

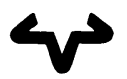

THE UNIVERSITY OF TEXAS PRESS

AUSTIN 
Portions of this work originally appeared as "Reading Sarmiento: Writing the Myths of National Culture," from Sarmiento and His Argentina, edited by Joseph T. Criscenti. Copyright (C) 1993 by Lynne Rienner Publishers, Inc. Used with permission of the publisher; and as "The Wiles of Disputation: Alberdi Reads Facundo," from Sarmiento: Author of a Nation, Donghi, Tulio Halperi, Iván Jaksic, et al. Copyright $\mathbb{C}$ I 994 The Regents of the University of California; and as "From Barbarism to Civilization: Travels of a Latin American Text," from American Literary History (1992) Vol. 4, 3: 443-463. By permission of Oxford University Press.

$$
\begin{gathered}
\text { Copyright }(1996 \text { by the University of Texas Press } \\
\text { All rights reserved } \\
\text { Printed in the United States of America } \\
\text { First edition, } 1996
\end{gathered}
$$

Requests for permission to reproduce material from this work should be sent to Permissions, University of Texas Press, P.O. Box 78 I 9 , Austin, TX 78713-7819.

(2) The paper used in this publication meets the minimum requirements of American National Standard for Information Sciences-Permanence of Paper for Printed Library Materials, ANSI Z39.48-1984.

Library of Congress Cataloging-in-Publication Data

Goodrich, Diana Sorensen.

Facundo and the construction of Argentine culture / by Diana Sorensen Goodrich.

p. $\quad \mathrm{cm}$.

Includes bibliographical references (p. ) and index. ISBN 978-0-292-72790-8

I. Sarmiento, Domingo Faustino, I 8 I I- I 888. Facundo.

2. Argentina-History-1810- 3. Argentina-Intellectual life.

I. Title.

F2846.5247G6 1996

$982-\mathrm{dc} 20$

$95-52564$ 
For my daughter Lisa 
THIS PAGE INTENTIONALLY LEFT BLANK 